\title{
初期温度履歴をうける壁状マスコンクリート構造体の ひびわれ発生実験
}

\section{EXPERIMENTAL STUDY ON THERMAL CRACKS OF MASS CONCRETE WALL WITH EARLY AGE THERMAL HISTORY}

\author{
山 崎 做敏* \\ Masatoshi YAMAZAKI
}

\begin{abstract}
The object of this experimental study is to clarify the effect of temperature declining rate of mass concrete on thermal crack occurrence of mass concrete wall structure restricted by foundation with high rigidity.

Three specimens are prepared, and they have same experimental conditions except their cooling. rates from high temperature to room temperature. Cracks observed when shutterings were removed from the specimen after the temperature history finished. Ages of crack occurrence were detected through the concrete strain gages embedded in the foundation.

As a result, it is deduced that the temperature declining rate did not affect on the crack formation of the mass concrete.
\end{abstract}

Keywords : mass concrete, thermal stress, thermal crack, cooling rate マスコンクリート, 温度応力, 温度ひびわれ, 冷却速度

1. 序

底面から連続拘束を受ける壁状マスコンクリートでは 温度降下時に生じる冷却収縮が，底面から拘束される事 によって引張応力を生じ, 往々にして温度ひびわれを発 生させる。

本実験研究では，壁状マスコンクリリートの温度ひびわ れの発生の状況を奏験的に検討したものであり,とくに， 温度降下速度をパラメーターとして, 温度降下速度の違 いによるひびわれの発生のしやすさを評価することを主 眼として，実験的に検討したものである。

\section{2. 既往研究の概観}

壁状マスコンクリートの温度ひびわれについては, 筆 者が, 温度降下量と $L / H$ (壁長亡壁高さの比) との関係, およびひびわれ状況について実験検討した結果を報告し だ”。の際に既往の研究のうち，特に底面から連続拘 束を受けるマスコンクリートの研究について概観してい るのでここでは省略する。

温度降下速度については，既往のいくつかの文献（工 事報告・実験研究報告など）について温度降下速度を算

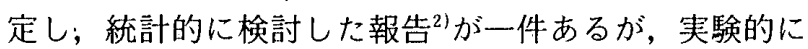

検討したものはまだないようである。

\section{3. 実験方法・試験体}

マスコンクリートの実験は, 温度条件を再現させる必 要から，必然的に大規模な実験となるのが一般的である が，規模の大きい実験は実験の実施に当たって費用や実 験場所等の色々な面で困難である。

本実験では, 若干の工夫により小型のマスコンクリー 卜試験体によって実験した。試験体の形状寸法を図一1

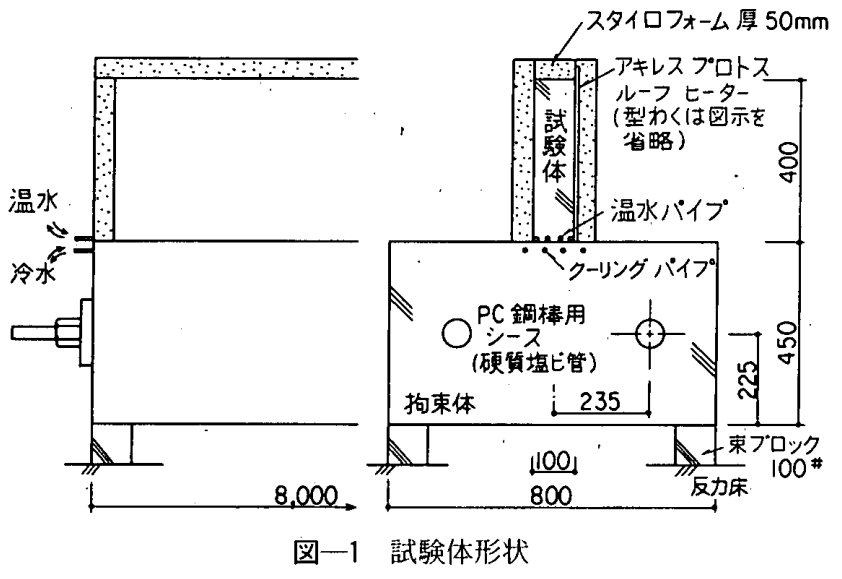

本論文の一部は, 参考文献 3）4）に発表した。また, 参考文献1)の一部を再揭した。

* 鹿島技術研究所第二研究部 専門部長 Chief Research Engineer, Building Engineering Department, Kajima Technical Research Institute 


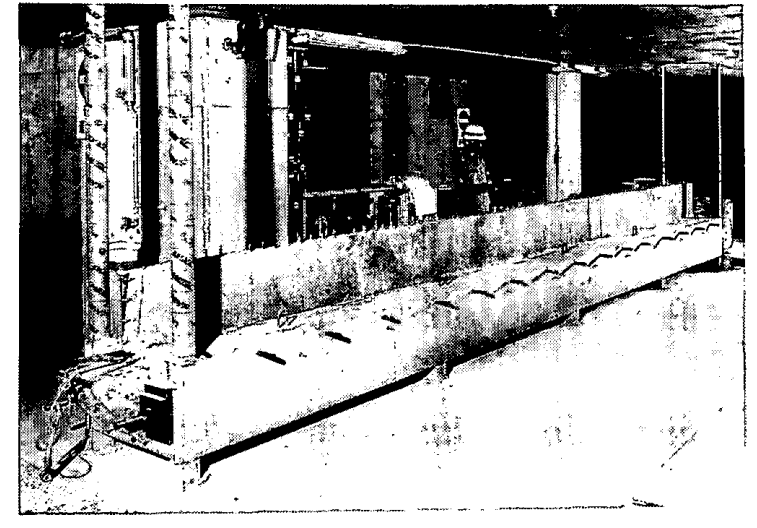

写真一1 実験状況

に示す。試験方法は参考文献 1) で詳述したものと同様 であるのでここでは概略を述べるに止める。

マスコンクリートを模擬する壁状(あるいは基礎梁状) の試験部分は, 壁厚 $10 \mathrm{~cm}$, 壁高 $40 \mathrm{~cm}$, 長さ $8 \mathrm{~m}$ とし, この壁に比べて十分に剛な断面を持つ拘束体の上に打設 するものとした。試験体の長さは，ひびわれ間隔のばら つきを考虑して，十分長くとってひびわれ発生数を多く 得られるように配慮した。拘束体としては, 幅 $80 \mathrm{~cm}$, 高さ $45 \mathrm{~cm}$ の断面を持つ基礎ブロックを設けている。

実験状海を写真一 1 に示す。

壁部に面状発熱体を取付け, 温度を外部からコント ロールするとともに，壁部を断熱板で包み，マスコンク リートを模擬した温度（後述）を履歴させた。

\section{4. 実験計画とパラメーター}

今回新たに実施した試験体は, 温度急降下試験体と緩 降下試験体の二体であり, 温度降下速度をパラメーター とした実験である。参考文献 1）のNo. 4 試験体を温度 降下速度が標準の試験体として含めて計三体としてい る。後述するように, 温度降下速度には, 標準的な速度 といったものは存在しないので急降下・標準・緩降下と 名付けても実構造体とのダイレクトな対応を想定したも のではない。

温度降下速度をパラメーターとするにあたり, 温度降 下開始までの温度履歴は各試験体に共通となるように し, 温度降下開始以後の速度のみをパラメーターとした。 鉄筋量などもパラメーターとしては採用しない。水平方 向はすべて無筋である。

昇温速度は参考文献 1）No.4 試験体のそれに合わせ た。これは参考文献 1) のNo.1〜4 試験体において, 昇温速度大な No. 4 試験体が大きい引張応力を生じさせ ることを考慮し，ひびわれの発生しやすいように選んだ ものである。

計画温度履歴を図一2に示す。試験体の一覧を表一1 に示す。

温度降下速度の定義としては, 文献 2）に次の式（1）

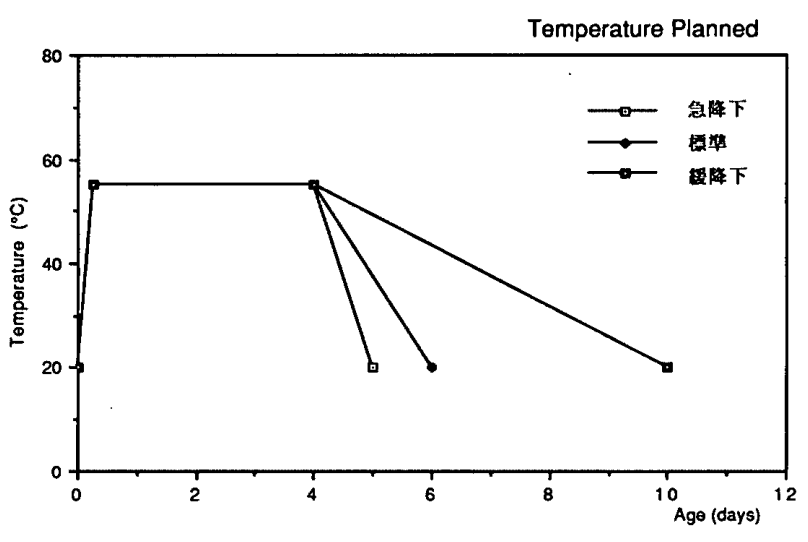

図一2 計画温度履歴

表一1 試験体一覽（計画値）

\begin{tabular}{|lcccc|}
\hline & 昇温速度 & 最高温度 & 降温速度 \\
\hline 急降下試験体 & $35^{\circ} \mathrm{C} / 0.25$ day & $55^{\circ} \mathrm{C}$ & $35^{\circ} \mathrm{C} / 1$ day \\
標準試験体 & $\prime \prime$ & $\prime \prime$ & $35^{\circ} \mathrm{C} / 2$ day \\
缓降下試験体 & $\prime \prime$ & $\prime \prime$ & $35^{\circ} \mathrm{C} / 6$ day \\
\hline
\end{tabular}

標準は参考文献1)報告実験のNo.4試験体で代用

のような定義例がある。ここでは，本実験に合わせて式

（2）の形にして用いることとした。

温度降下速度 $=\{($ コンクリート最高温度 $)-($ 平常 に戻った温度 $)\} /\{($ 平常時に戻っ た材令)ー(コンクリート温度最高 時材令 $)\}$

温度降下速度 $=l($ 冷却開始時温度 $)-($ 平常に戻っ た温度 $)\} /$ (平常に戻った材令 $)-$ (冷却開始時材令)\}

実部材では温度履歴の曲線は，ピーク付近では上に凸 その後の大部分では上に凹の特性を持っており, 曲線の 特性は逆 S字状である。また, 安定温度付近の温度履歴 曲線はかなりなだらかな勾配を持っているものであり， 安定時温度到達時刻の評価はかなり怨意的にならざるを 得ないものである。このため, ピークと安定温度時とを 直線で結ぶ温度降下速度という概念はかなりマクロなも のである。

以上の事から，実験計画における温度降下速度と実部 材における温度降下速度との対応は，この実験で降下速 度が意味ある結果を持った時以降に必要とあれば考慮す ることとし，直線で代用するということで十分と判断し た。

温度降下速度の設定に当たっては, 実際の構造物にお ける温度降下速度を設定の基本とするべきであるが，実 際のマスコンクリートでは温度降下速度は主として構造 物の規模（断面最小寸法など）で決まってしまうもので あるので，実部材との対応を考えるためには，実部材の 

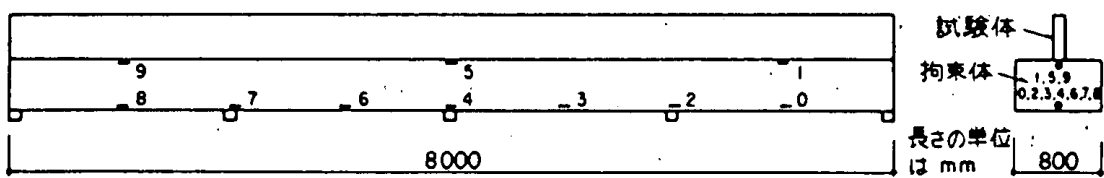

8

図一3埋め込み型ひずみ計配置図

規模を限定する必要がある。また，広い範囲の実部材を 対象亡し，それぞれに標準降下速度と急降下・緩降下速 度を採るとすると実験上，極めて多数のケースを考慮し なければならないが，これは，温度降下速度がひびわれ 抑制の点から意味を持うパラメーターであることが本実 験により確認された場合に，必要に応じて改めて考慮す ることで十分と判断し，今回のようなパラメーターの設 定とした。

参考文献 2)で扱っている既往文献からの温度降下速 度と, 本実験における温度降下速度 (実験結果) の範囲 との関係は次のとおりである。

参考文献 2)(全事例) $13.9 \sim 0.73^{\circ} \mathrm{C} /$ day

同（壁状構造のみ*） $13.9 \sim 3.5{ }^{\circ} \mathrm{C} /$ day

* 高速道路側壁, L 型けい船岸など 本実験結果（降下開始以降） $21.6 \sim 6.7{ }^{\circ} \mathrm{C} /$ day

\section{5. 測定項目・測定位置}

測定項目はひびわれ（目視による観察）のほか，コン クリートなどの温度，および拘束体コンクリートのひず みである。

温度測定は, いずれも銅コンスタンタン熱電対を埋設 することにより行った。補償導線はエナメル被覆 0.2 $\mathrm{mm} \phi$ のものである。測定はデジタルひずみ測定器 ( T 測 器社製 TDS 501 型）を用い自動計測を行った。測定間 隔は 30 分である。

ひびわれ観察は，試験体が邻えて，温度が室温に達し た時，型枠を外して行った。ひびわれパターン・ひびわ れ間隔・ひびわれ幅を観察・測定した。ひびわれ幅測定 はペーパークラックゲージにより行った。

ひびわれ発生材令は直接には測定しなかった。これを 測定するためには，ひずみ計・応力計の類を埋設する必 要があるが，断面が小さい試験体でこの種の計器の埋設 をするとひびわれの誘発原因となるため行わなかった。 ひびわれの発生材令と順序は，下部拘束体内に埋込み型 ひずみ計を埋設して測定した。すなわち，ひびわれ発生 による影響が拘束体に及ぼす影響を，拘束体のひずみ変 化として検出したものである。埋込み型ひずみ計の配置 を図一3に示す。

\section{6. コンクリート調合}

コンクリートは普通コンクリートとした。調合は建築 工事でマスコンクリート工事に一般に用いられる程度の セメント量のコンクリートとし，一種類とした。3体と
も同一調合である。

調合表を表一2に示す。

\section{7. 材料試験結果}

コンクリート関係の材料試験はコンクリート王縮およ 表一2. 使用材料之調合計画

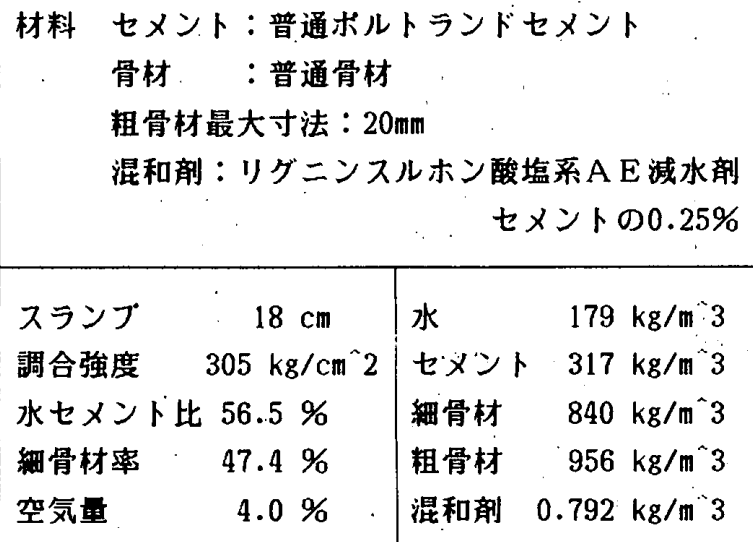

表一3 強度発現状況および線膨張係数

[急降下試験体]

\begin{tabular}{|c|c|c|}
\hline & 標準㮹生 & 温水恙生 \\
\hline 試験材令 & $7 \quad 27$ & $\begin{array}{lll}4 & 7 . & 27\end{array}$ \\
\hline 引張強度 & -14.123 .3 & $\begin{array}{lllll}13.8 & 15.1 & 18.8 & 19.8 & 23.3\end{array}$ \\
\hline 压縮強度 & $147 \quad 233$ & $\begin{array}{lllll}113 & 155 & 186 & 193 & 208\end{array}$ \\
\hline ヤング率 & 1.922 .51 & $1.77 \quad 1.84 \quad 2.02 \quad 2.11 \quad 2.26$ \\
\hline 線膨張係 & & $10^{*}-6$ \\
\hline
\end{tabular}

[緩降下試験体]

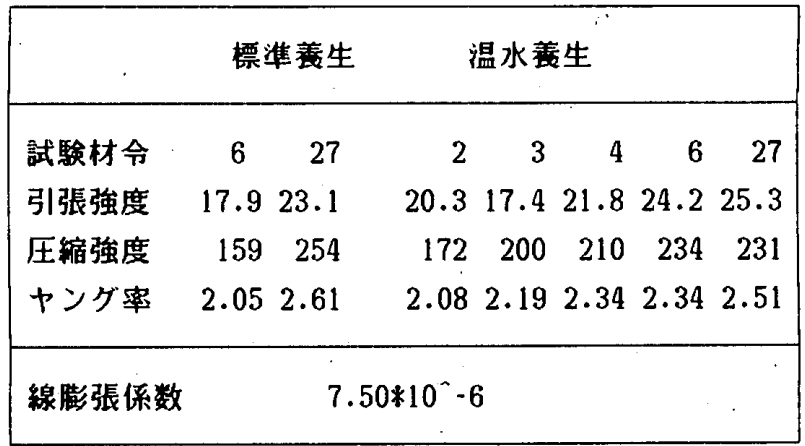

試駼材令は 日 強度の単位は $\mathrm{kg} / \mathrm{cm}^{\prime 2} 2$ ヤング密の単位は $10^{\wedge} 5 \mathrm{~kg} / \mathrm{cm}^{\wedge} 2$ 線膨張係数の単位は $1{ }^{\circ} \mathrm{C}$ 
び引張強度・ヤング係数・線膨脹係数について行った。 材料試験結果を表一3に示す。供試体はいずれも $10 \phi$ $* 20 \mathrm{~cm}$ のシリンダーである。各々の試験体のコンク リートについてそれぞれ材料試験を実施した。

表中の温水養生とは, 温水槽中にテストピースを打設 直後から浸漬しておいたものである。この温水槽は試験 体部分の温度を計画温度に保つための温水循環パイプに 供給する温水を貯留しておくものであり，試験体と同一 の温度履歴をさせたものである。

\section{8. 実験結果}

\section{1 温度履歴亡断面内温度分布}

温度履歴について図一4に示す。打ち込み時コンク リート温度・平坦部温度 (後述) の平均温度・最終女定 温度などの一覧を表一 4 に示す。

なお，本実験では温度履歴曲線がほぼ台形であり，温 度降下開始以前の高原状温度ではその平均值に意味があ るので,これを平坦部温度と唱えることにした。標準試 験体の温度履歴曲線において, 昇温から平坦部に移ると きに小さなピークが発生したが，このような温度は無視 することとした。

断面内の温度分布の一例を図一 5 に示す。面状発熱体 と壁の高さとがほぼ同じ寸法であったため,コンクリー 卜は均等に加熱され，断面の温度分布はほぼ一様である。 他の試験体の温度分布は図を省略したが，これもほぼ同 じである。試験体厚方向の温度差は試験体にもよるが約 $3^{\circ} \mathrm{C}$ であった。以後のコンクリート温度は断面中心の温

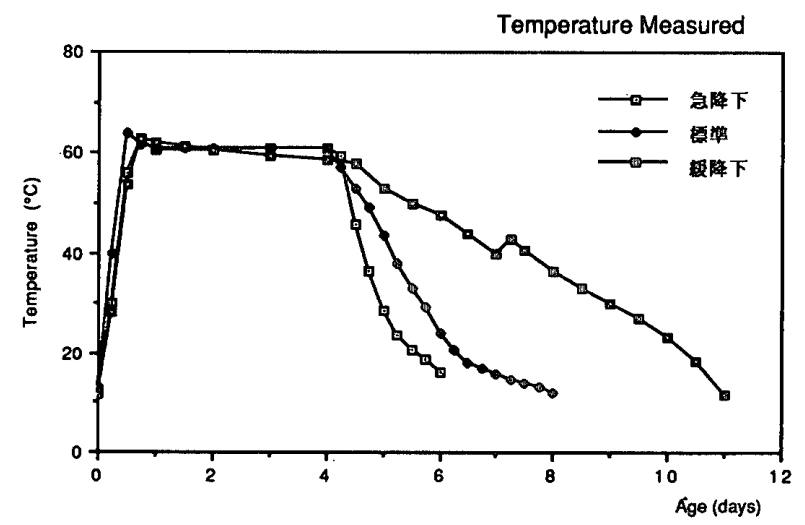

図一4 温度履歴実測結果

表一4 試験の実施経過と温度関係データ一覧

打込温度 平坦部温度 最終安定温度 降温速度

\begin{tabular}{|llllr}
\hline 急降下 & 14.4 & 61.0 & 13.1 & 21.6 \\
標準 & 12.9 & 61.1 & 12.2 & 12.3 \\
緩降下 & 11.7 & 59.7 & 11.6 & 6.7 \\
\hline
\end{tabular}

温度の単位は ${ }^{\circ} \mathrm{C}$

降温速度の単位は $\mathrm{C} / \mathrm{day}$
度で代表させた。

8.2 ひびわれの状況

脱型は, 温度の安定した時点（試験体の温度履歴によ りそれぞれ材令 $6,8,11$ 日) で, 温度が室温にほぼ等し いことを確認してから実施した。この時のひびわれパ ターンの観察結果を図一6に，ひびわれ間隔などの概要 を表一 5 に示す。

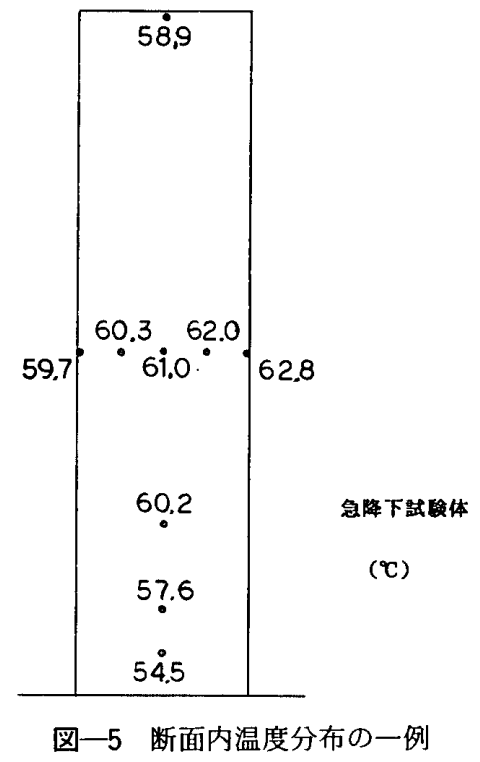

急降下

\begin{tabular}{|lll|l|l|l|}
\hline & $T$ & & & 1 \\
\hline 1.3 & 3.2 & 4.5 & 5,2 & 6.5 \\
\hline
\end{tabular}

蹗隼

\begin{tabular}{|c|c|c|c|c|c|}
\hline & & & & $\mid$ & 战騷体 \\
\hline 1.622 & 3.7 & 4.8 & 5.7 & 拘束休 \\
\hline
\end{tabular}

锗下

\begin{tabular}{|c|c|c|c|c|c|}
\hline & & & & & $\mid$ \\
\hline 1.4 & 2.6 & 3.5 & 4.6 & 5.5 & 6.9 \\
\hline
\end{tabular}

$8 \mathrm{~m}$

図一6 ひびわれパターンとひびわれ位置（脱型時）

表一5 脱型時ひびわれ幅の実測值（最大幅*）など

\begin{tabular}{|c|c|c|c|c|}
\hline 試験体名 & & 急降下 & 標準 & 缓降下 \\
\hline 全温度降下量 & ${ }^{\circ} \mathrm{C}$ & 48 & 49 & 48 \\
\hline ひびわれ数 & 本 & 5 & 5 & 6 \\
\hline 平均ひびわれ間隔 & $\mathrm{cm}$ & 133 & 133 & 114 \\
\hline 平均 $\mathrm{L} / \mathrm{H}$ ** & & 3.33 & 3.33 & 2.86 \\
\hline ひどわれ幅最大值 & $\mathrm{mm}$ & 0.25 & 0.40 & 0.35 \\
\hline ひびわれ幅の和 & $\mathrm{mm}$ & 1.05 & 1.40 & 1.33 \\
\hline 平均ひびわれ幅 & $\mathrm{mm}$ & 0.21 & 0.28 & 0.22 \\
\hline
\end{tabular}

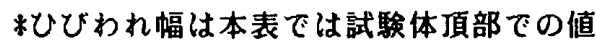
**ここにL/Hは壁長 L（ここでは平均 ひびわれ間隔）を壁高 $\mathrm{H}$ で除した值 

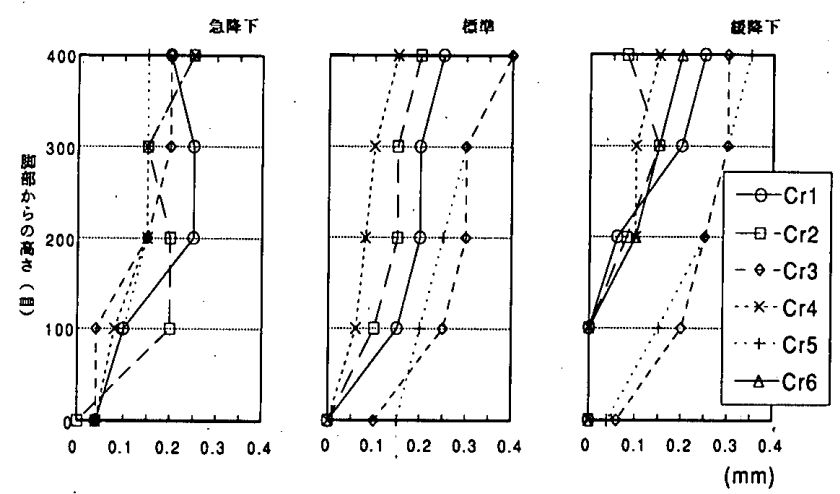

図一7．脱型時ひびわれ幅

ひびわれは，上下方向に生じ，壁厚を貫通しており， 上部で広く，下部で狭いV字形であった。ひびわれの形 状として各ひびわれを脚部から頂部までの 5 力所で夷測 した結果の詳細を図一7に示す。ひびわれが頂部で広く， 下端で 0 の三角形分布をしているのは，上下方向に温度 が一定であることと，拘束が底辺からのみであることに よるものであろう。

これらの結果を見ると次のことが言える。

1）ひびわれの本数については, 温度降下速度の大小と は関係が認められない。

2）ひびわれ幅については，最大幅・平均幅ともに温度 降下速度の大小とはなんら関係が認められない。

\section{3 ひびわれ発生時刻の推定}

拘束体下面 7 力所に埋設した埋め込み型ひずみ計の測 定結果を図一8.1.1〜8.3.3に示す。図中の曲線の錯綜 を避けるため，1 試験体分の曲線を 3 枚の図に分け，さ らに若干の測定点については温度降下開始点以前のデー 夕を省略してある。

なお，埋め込み型ひずみ計のうち，拘束体上ば側に埋 設したひずみ計は次に述べる段差の検出が鈍感であるの で揭載を省略した。

図中で曲線に段差のあるところはひずみが急激に変化 したところであり，ひびわれが武験体に発生したことに よる拘束体のひずみ変化と見なせる。したがって，ひず み測定值の出力が段差を示す時刻と，脱型後に観察した ひびわれ発生位置，および埋め込みひずみ計の位置とか ら，それぞれのひびわれは図中に示す時刻に発生したこ とが推定される。ひびわれ発生時刻・発生順序・発生ま での温度降下量をまとめて表一6に示す。

なお，図一8.2.3中の*マークについては，6本目の ひびわれは目視では確認されていない。近傍のひびわれ の拡幅かとも推定される。発生順序は別の組み合わせも 検討したが図中記入のものが最も妥当と判断した。また， 図一8.3.1の 3 本目については前後の関係から, 約 8 時 間生じた停電中に発生したものと推定した。

ひずみ計の測定結果を用い，試験体を連続梁と見なし て，ひびわれ発生による解放モーメント量の評価，解放

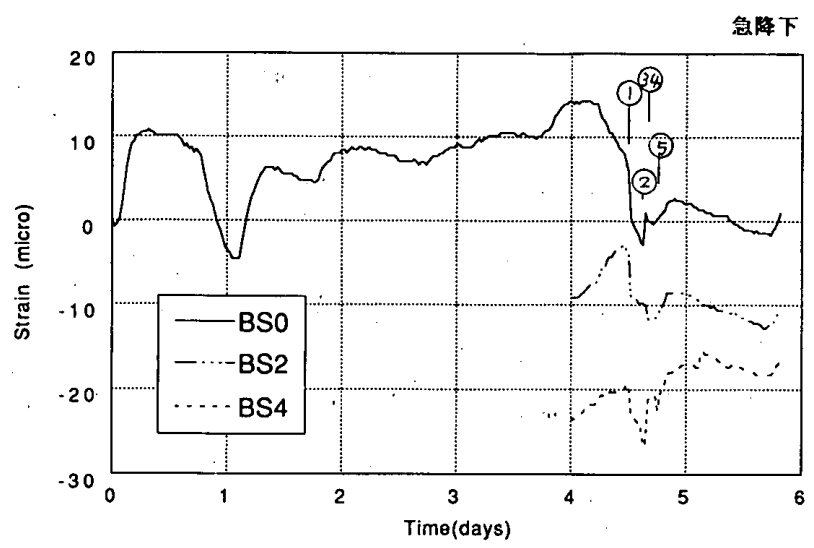

图一8.1.1 埋め込みひずみ計測定結果（急降下試験体）

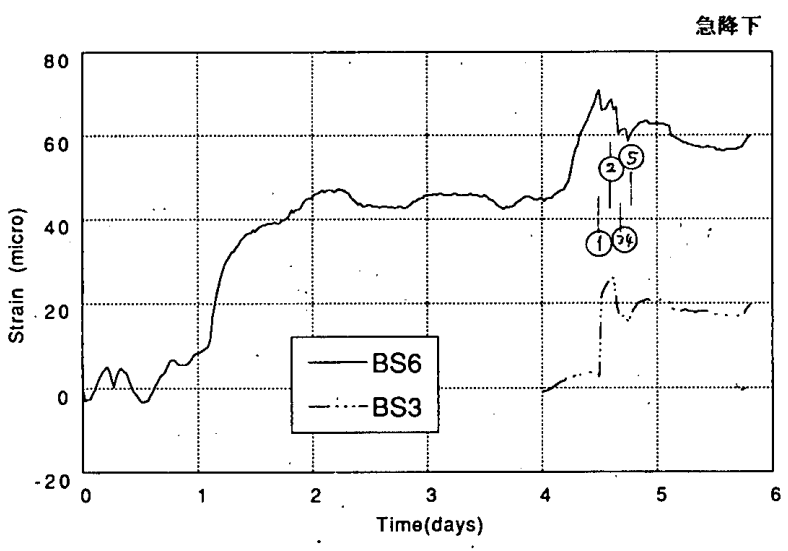

図一8.1.2 埋め込みひずみ計測定結果（急降下試験体）

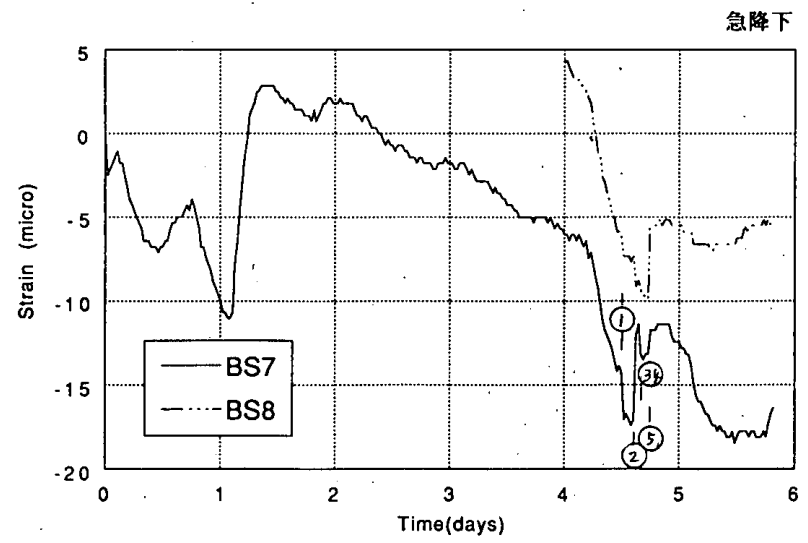

図一8.1.3 埋め込みひずみ計測定結果（急降下試験体）

モーメント量からひびわれ位置の算定なども試みたが, 見るべき結果は得られなかった。拘束体の支持条件がコ ンクリートブロックを束石とした，あいまいな支持によ る不静定構造であったためと思われる。

8.4 ひびわれ過程終了までの温度降下量と温度降下速 度亡の関係

ひびわれ発生の結果である本数・幅と温度降下速度と の関係が認められなかった (8.2 項) ので，ここではひ びわれ発生の途中経過における初ひびわれと温度降下速 度との関係を検討する。

最高温度からひびわれ発生時までの温度降下状況と, ひびわれ発生時刻之の関係の一例を図一9に示す。 


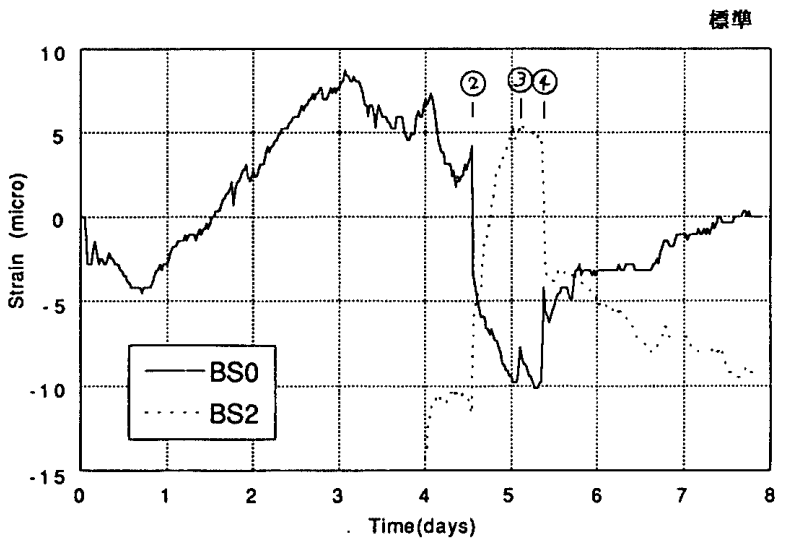

図一8.2.1 埋め込みひずみ計測定結果（標準武験体）

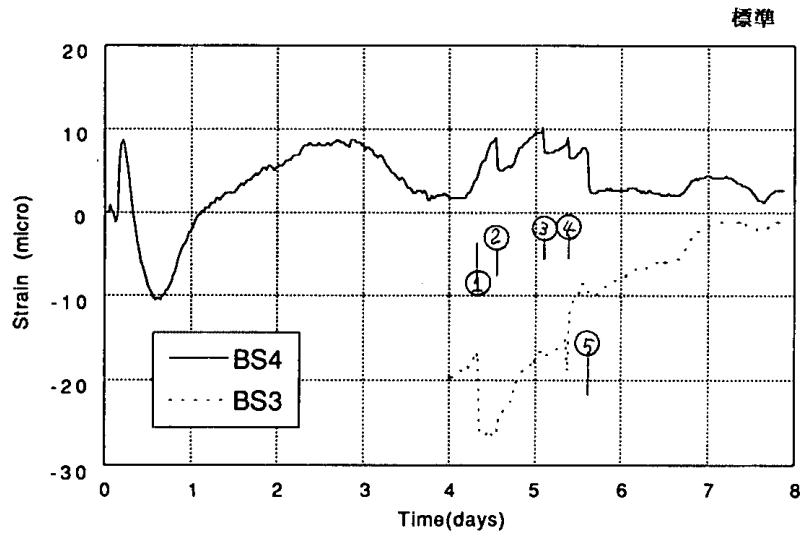

図一8.2.2 埋め込みひずみ計測定結果（標準試験体）

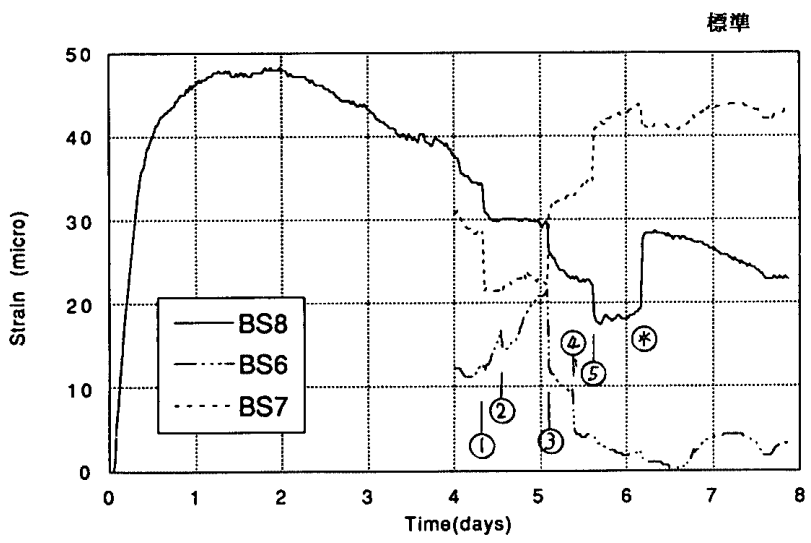

図一8.2.3 埋め込みひずみ計測定結果（標準試験体）

今回の実験は，温度降下が始まるまでの温度履歴が三 体の試験体において共通であって, 温度降下プロセスの みが異なるので温度降下速度の影響が直接に把握できる ものである。

初ひびわれ発生時刻, 発生までの温度降下などをまと めた表一6から次のことがいえよう。

（1）初ひびわれの発生は，比較的小さい温度降下量で 起こることが示された。(参考文献 1) で既述)

( 2 )初ひびわれと温度降下速度の関係を, 初ひびわれ発 生までの温度降下量の大小で見ると, ほとんど関係ない といえる。すなわち, ひびわれ発生のしやすさを降下開 始から初ひびわれ発生までの温度降下量で指標とするな
险降下

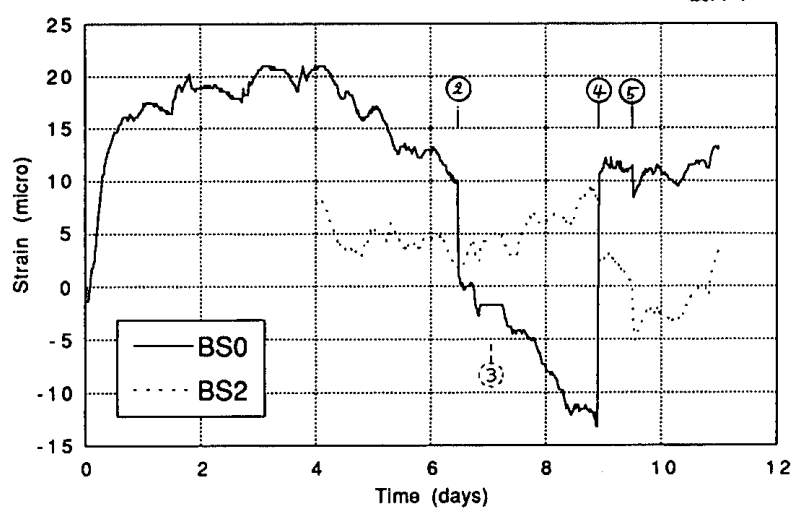

図一8.3.1 埋め込みひずみ計測定結果（緩降下試験体）

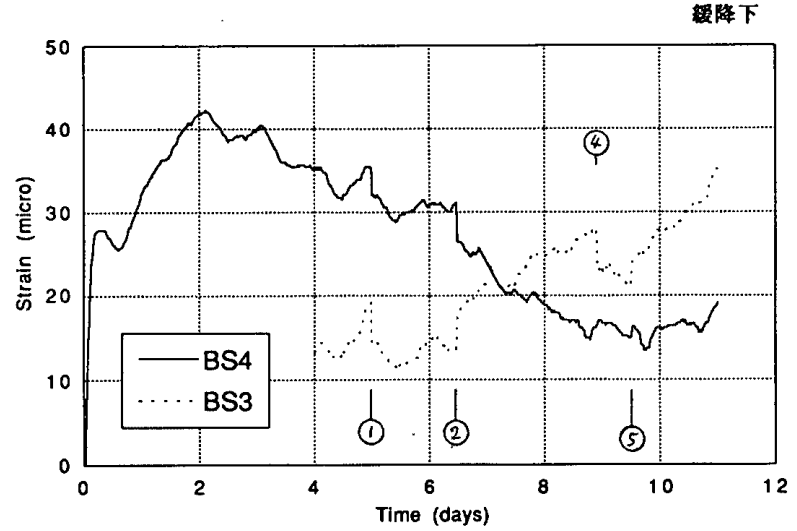

図一8.3.2 埋め込みひずみ計測定結果（緩降下試験体）

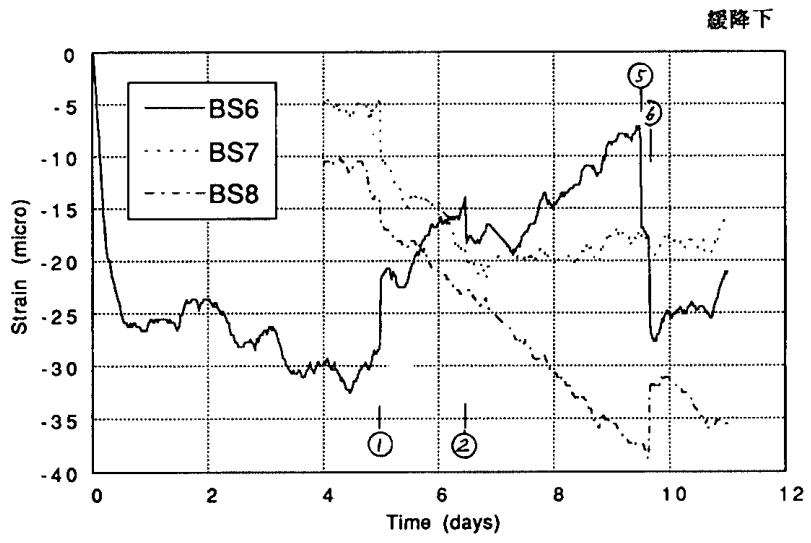

図一8.3.3 埋め込みひずみ計測定結果（緩降下試験体）

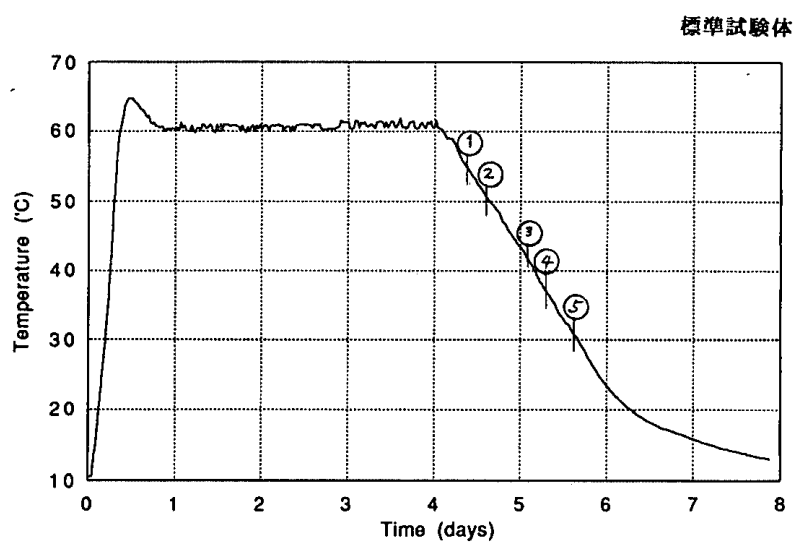

図一9温度履歴とひびわれ発生時刻 
表一6 ひびわれ時刻の推定結果

\begin{tabular}{|c|c|c|c|c|c|c|c|c|c|c|c|c|c|c|c|c|c|}
\hline \multirow{2}{*}{ : } & \multicolumn{6}{|c|}{ 急降下試験体 } & \multicolumn{5}{|c|}{ 摽準試験体 } & \multicolumn{6}{|c|}{ 緌降下試験体 } \\
\hline & & $6 r 1$. & $\mathrm{Cr} 2$ & $\mathrm{Cr} 3$ & $\mathrm{Cr} 4$ & 6.5 & $\mathrm{Cr} 1$ & $\mathrm{Cr} 2$ & $\mathrm{Cr} 3$ & $\mathrm{Cr} 4$ & $\operatorname{cr} 5$ & $\mathrm{Crl}$ & $\mathrm{Cr} 2$ & $\mathrm{Cr} 3$ & $\mathrm{Cr} 4$ & $\mathrm{Cr} 5$ & $\mathrm{Cr} 6$ \\
\hline 発生位置* & & 1.3 & 3.2 & 4.5 & 5.2 & 6.5 & 1.6 & 2.2 & 3.7 & 4.8 & 5.7 & 1.4 & 2.6 & 3.5 & 4.6 & 5.6 & 6.9 \\
\hline 降下時間料 & day & 0.6 & 0.4 & 0.5 & 0.3 & 0.5 & 0.6 & 1.4 & 0.4 & 1.6 & 1.1 & 5.1 & 2.4 & 0.5 & 5.0 & 1.9 & 4.4 \\
\hline 発生順 & & (5) & (2) & (4) & (1) & (3) & (2) & (9) & (1) & (5) & 3 & (6) & (3) & (1) & (5) & (2) & (4) \\
\hline 発生温度 & ${ }^{\circ} \mathrm{C}$ & 37 & 42 & 40 & 46 & 41 & 52 & 36 & 55 & 31 & 42 & 26 & 41 & 53 & 27 & 44 & 31 \\
\hline 降温量 $* * *$ & ${ }^{\circ} \mathrm{C}$ & 24 & 19 & 21 & 15 & 20 & 9 & 25 & 6 & 30 & 19 & 34 & 19 & 5 & 33 & 16 & 29 \\
\hline 壁長 **** & & 3.2 & 5.2 & 2.0 & 8.0 & 2.8 & 3.7 & 2.1 & 8.0 & 2.0 & 4.3 & 2.6 & 3.5 & 8.0 & .2 .1 & 4.5 & 2.4 \\
\hline $\mathrm{L} / \check{\mathrm{H}}$ & & 8.0 & 13.0 & 5.0 & 20.0 & 7.0 & 9.3 & 5.3 & 20.0 & 5.0 & 10.8 & 6.5 & 8.8 & 20.0 & 5.3 & 11.3 & 6.0 \\
\hline
\end{tabular}

* 発生位置とは: 全長8mの試駼体の一端からひびれれ迄の距離(m)

生降下時間とは、温度降下開始から初しびわれ発生迄の時間(day)

*** 降温量とは降下開始時から初ひびわれ時迄の温度降下量 (C)

**** 壁長とは、そのひどわれの発生直前の両隣のひびわれ間の距離 $(\mathrm{m})$

L/Hとは、壁長を壁高で除したもの

ら，表一6より降下速度の早い方から順に $15^{\circ} \mathrm{C}, 6^{\circ} \mathrm{C}$, $5^{\circ} \mathrm{C}$ となっており,・降下速度の速くてもひびわれは生じ やすくなるとはいい難い。

\section{9. 解析との比較検討}

日本コンクリート工学協会マスコンクリート温度応力 研究委員会によるコンペンセーション法占.を用いて解析 した結果を図一10に示す。計算に用いたインプットデー 夕は表一7に示す材料データと図一2 の温度履歴である。 表一7のデータは材料試験結果データそのものではな く，四週圧縮強度のみを用いて，JCI ひびわれ制御指針 に示された方法6)に基づいて定めた。これは，試験体ご とに若干のばらつきがあることを避けるために解析用 データを統一したものである。表一7に示すように，実 測の試験值と大きな相違はない。なお，材令 3 日以前の ヤング係数を $1 / 3$ 程度 (クリープ係数 $\phi=2)$ に評価し て計算に用いた。このプロセスは, 参考文献 1) におけ る解析方法を踏襲したものである。

解析用温度履歴に計画值を用いたのは, 計算結果とし て得られる応力の, 試験体間のわずかな相違を, 傾向と して検出しようと意図したためである。

解析結果の図一 10 に示すように，温度降下が始まる

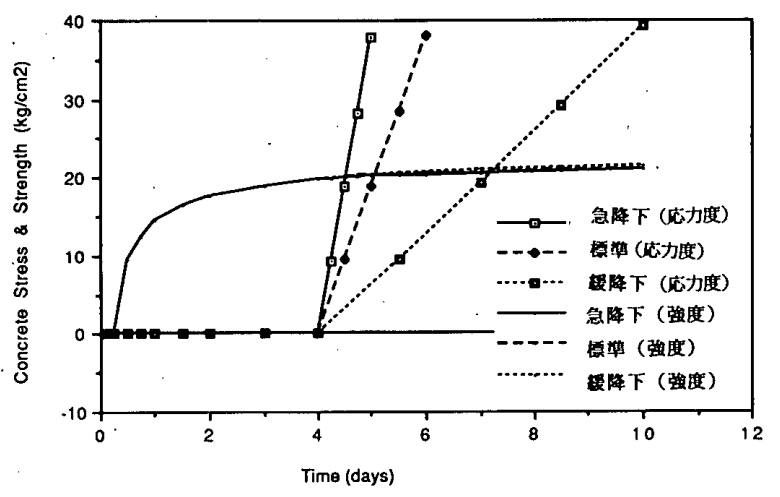

図一10 応力解析結果
表一7 応力解析のインプットデータ

\begin{tabular}{|c|c|c|c|}
\hline . & \multicolumn{2}{|c|}{ 解析入力値 } & 参考用実測結果 \\
\hline 28日圧縮強度 & $*$ & 256 & $233 \sim 272$ \\
\hline ヤング係数 & 站 & 2.45 & $2.42 \sim 2.61$ \\
\hline \multicolumn{4}{|l|}{ その他のデータ } \\
\hline 拘束係数 & $\mathrm{Rn}$ & 0.95 & - \\
\hline$\prime \prime$ & $\operatorname{RmL} .2$ & 1.0 & - \\
\hline 楾膨張倸数 & $* * *$ & 7.8 & $7.5 \sim 7.9$ \\
\hline クリープ係数 & $\phi(t<=3)$ & 2.0 & - \\
\hline$"$ & $(t>3)$ & 0.5 & - \\
\hline
\end{tabular}

*圧縮強度の単位は $\mathrm{kg} / \mathrm{cm}^{2}$ 料、ヤング係数の単位は $10 \% 5 \mathrm{~kg} / \mathrm{cm}^{2}$ *粰楾膨張係数の単位は $10 \cdots-6 / \mathrm{C}$

までは応力履歴は共通である。温度降下開始時以降は温 度降下速度の相違により，異なった応力履歴となる。そ して，緩降下ほど応力も大の傾向である。応力の大小は， それぞれの温度履歴の差によるマチュリティーの差がヤ ング係数の差となり,応力解析結果に表れたに過ぎない。 そして, 応力の最終值で比較すると急降下・標準・緩降 下試験体で $37.7 ， 38.1 ， 39.2 \mathrm{~kg} / \mathrm{cm}^{2}$ とその差はわずか なものである。また, 引張強度の增進量の試験体間の差 もわずかである。このような差が，ひびわれ実験で検出 されないとしても，ひびわれ発生現象のばらつきを考慮 すれば，当然のことと考えられる。

なお, 解析結果の引張応力の大きさと, 実験結果の初 ひびわれ発生状況之を比較すると, 引張応力が引張強度 よりも小さい状況でひびわれ発生が認められる。参考文 献 1）では引張強度の $60 \%$ 程度と評価しているが, こ の程度のものがここでも再現されていると見られる。 


\section{0. 結果のまとめ}

温度降下速度をパラメータとした奏験を行い，温度降 下速度とひびわれの発生しやすさとの関係を求めた。本 実験の範囲の結果をまとめると次のようである。

イ）温度降下速度と冷却後のひびわれ（の幅と数）

今回の実験範囲でいえば，発生したひびわれ（の数と

幅）と温度降下速度とは関係がなかった。

ひびわれ幅は温度急降下の試験体では最大 $0.25 \mathrm{~mm}$ であったが，その倍の時間をかけてゆっくり温度降下さ せた標準試験体では最大で $0.4 \mathrm{~mm}$ ，さらにゆっくりな 緩降下試験体で $0.35 \mathrm{~mm}$ であった。ひびわれ幅は温度 降下速度の最も速いほうがひびわれ幅の狭いものが発生 したということでもある。

口）温度降下速度とひびわれ発生までの温度降下量 ひびわれの発生しやすさをひびわれ発生までの温度降 下量で示すと, 温度降下速度の速いほうがひびわれは出 やすいとはいえない。

温度降下速度とひびわれとの関係は，おそらく，引張 応力の発生しやすさで決まると思われるが, 温度降下速 度が引張応力に影響するのは，降下速度がゆっくりな場 合に引張応力の緩和にクリープの貢献するためであり， すでにかなり硬化しているコンクリートにおいては，ク リープの寄与はわずか数日の違いではあまり効いてこな いものと想像される。

\section{参考文献}

1) 山猗敌敏：底面で連続拘束を受ける壁状マスコンクリー 卜構造体の温度応力とひびわれに関する基礎実験研究, 日本建築学会構造系論文報告集, 第 394 号, pp. 27 36, 昭和 63 年 12 月

2）森永 繁, 桑原隆司：マスコンクリートの水和熱による きれつ防止を目的とした施工法，コンクリート構造物の ひびわれに関するシンポジウム発表論文集 2-10, 日本コ ンクリート工学協会, pp. $113 \sim 118$, 昭和 52 年 3 月 16 日

3）山崎敞敏：底面で連続拘束を受ける壁状マスコンクリー 卜構造体の温度応力とひびわれに関する基礎㬰験（その 2), 日本建築学会大会学術講演梗概集 (九州) 材料施工 1302, pp. 603 -604, 1989 年 10 月

4）山崎敞敏：底面で連続拘束を受ける壁状マスコンクリー 卜構造体の温度応力とひびわれに関する基礎実験（その $3), 1989$ 年度日本建築学会関東支部研究報告集材料施工 6, pp. $213 \sim 216$

5）マスコンクリートの温度・态力計算用パソコンプログラ ム：マスコンクリートの温度応力研究委員会：日本コン クリート工学協会 1989 年 6 月

6) マスコンクリートのひびわれ制御指針, p. 67, 材料の力 学的性質と熱膨張係数, 日本コンクリート工学協会, 1986 年

(1991 年 11 月 8 日原稿受理, 1992 年 5 月 6 日採用決定) 